\title{
A description of four types of otolith opaque zone
}

\author{
Satoshi Katayama ${ }^{1}$
}

Received: 9 March 2018 / Accepted: 8 June 2018 / Published online: 13 July 2018

(c) The Author(s) 2018

\begin{abstract}
Analysis of the alternating opaque and translucent zones in fish otoliths is a widely used method to determine age in fish. The mechanisms underlying the annual periodicities in the formation of these zones remain unknown, although various interpretations and explanations have been presented to explain the appearance of the opaque zones. Here I review the biological and structural characteristics of the opaque zones in otoliths from a number of fish species. The results of this review suggest that the opaque zones can be classified into four different types. Type A is a dark opaque zone, displaying minute, dense crystals, and is typically formed at a young life-history stage. Type B comprises an aggregation of grooves and discontinuous crystals that are formed during growth-stagnant periods. Type $\mathrm{C}$ can be described as a washy black zone that has the appearance of an object that is smeared with ink; it is formed during seasons of active growth. Type D has deep grooves, appears luminous in transmitted light in etched otolith sections, and is formed during the spawning season. Types $\mathrm{A}$ and $\mathrm{C}$ otolith opaque zones are typical of younger fish and are formed during growing periods. They are complementary to Types $\mathrm{B}$ and $\mathrm{D}$ otolith opaque zones which are formed during periods of stagnant growth and/or during the spawning seasons and which are typical of older fish, which generally lack Type A zones. To ensure precise age determination in fish, it is therefore necessary to understand the structural and biological characteristics that produce these four distinct types of opaque zones.
\end{abstract}

Keywords Age determination $\cdot$ Annulus $\cdot$ Otolith $\cdot$ Opaque zone

\section{Introduction}

Age determination is an essential component of fishery assessment and fish population analysis, as well as important to a better understanding of animal life history and biology. Detailed information on age is required for life-history tables which document an organism's mortality (or survival) and reproduction rate (maturation rate) as a function of age. Although molting times are utilized in life-history tables for some crustaceans or insects, fisheries generally use the age-dependent year. Age information is also required the aim is to examine the growth patterns of fish. Fisheries researchers generally express the relationship of body length to age using growth curves and/or growth formulas. The Bertalanffy growth formula, Gompertz formula, logistic formula, and other sigmoid formulas relate regressed body

Satoshi Katayama

skata@m.tohoku.ac.jp

1 Graduate School of Agricultural Science, Tohoku University, 468-1 Aramaki Aza Aoba, Aoba-ku, Sendai, Miyagi 980-8572, Japan length to age data and are utilized to express the growth traits of species, variations in growth patterns among species, and growth rates of populations (Akamine 2007). Such analyses are an essential process in fisheries biology (Jones 2002). Determining the age composition of a fisheries catch and catch number also require age data. These calculations contribute to our knowledge of mortality, recruitment, and other fundamental population parameters. The proportion of fish of different age groups in a catch or in the population is called the age composition and is closely related to population dynamics and fishing pressure. Catch number by age is necessary to estimate the year class strength.

Growth is strongly influenced by environmental conditions, and variations in the environment are likely to affect the growth rates of body tissues. Changes in growth rate may be visible as growth lines or abrupt discontinuities in the hard parts of fish, such as scales, opercular bones, vertebrae, otoliths, and the spinal cord. Otoliths are generally used to examine growth rate as they are easier to read than scales, and the analysis of otoliths has been found to provide more accurate results of growth rate because they are not 
resorbed or regenerated (Mugiya 1997; Morales-Nin and Panfili 2002).

Fish otoliths consist of accreted layers of calcium carbonate and a gelatinous matrix that fish produce throughout their lives. For the majority of fish species, the sagittal otolith contains growth information over the broadest age range of an individual (Campana 2001). It has been shown that changes in the opacity of otoliths are caused by differences in growth rate (Hüssy and Mosegaard 2004), age, metabolism (Hoff and Fuiman 1993; Høie and Folkvord 2006), and sexual maturity (Beckman and Wilson 1995; Høie and Folkvord 2006). Environmental factors can also play a role, and poor feeding conditions (Neilson and Geen 1985) in addition to temperature and photoperiod (Beckman and Wilson 1995) have been shown to affect otolith opacity. Theoretical advances in the modeling of fish otolith biomineralization using a bioenergetic approach have also recently been reported (Fablet et al. 2011).

Two seasonal zones, namely, the opaque and the translucent zones, can often be distinguished in otoliths based on different opacities. Under transmitted light the opaque zone is dark and the translucent zone is bright (Wright et al. 2002). Alternating opaque and translucent zones in fish otoliths are widely used for age determination, with the number of opaque zones widely considered to be the age of the fish in years. However, in not a few species it is not easy to count the opaque zones (Iizuka and Katayama 2008). Thus, an improved understanding of the structural characteristics and formation patterns of the opaque zone would potentially improve the accuracy of age estimations. In this review, the structural characteristics of the opaque zones are described based on observations of the macro-optical features of the whole otolith, sections of the inner otolith structure, and the crystal structure using scanning electron microscopy (SEM) imagery. Distinct types of opaque zones are formed during different phases of the life cycle. Although the lapilli and asteriscus otoliths can be used for age determination in Cypriniformes fishes (Iizuka and Katayama 2008), in this review I refer only to sagittal otoliths.

\section{Methods}

To view the whole otolith surface, individual otoliths were immersed in water or alcohol and viewed directly using reflected light (magnification 2-10×). When the background is dark or black, opaque and translucent zones are visible as white and black zones, respectively.

To examine otolith sections, the otoliths were mounted and embedded in polyester resin and cut into approximately 0.2-mm transverse sections using a diamond saw (Leica sp1600; Leica Microsystems GmbH, Wetzlar, Germany). These sections were mounted onto glass slides and their surfaces then ground to increasingly finer grades using Carborundum paper. The sections were then etched with $0.2 \mathrm{~N}$ $\mathrm{HCl}$ for $40-60 \mathrm{~s}$ to highlight the microstructure in the otoliths. These sections were then observed under a binocular microscope (magnification 10-40 $\times$ ) with transmitted light and by SEM (Miniscope TM3030; Tabletop Scanning Electron Microscope, Hitachi, Japan) (magnification 80-1000×). In some cases, enamel paint was applied to smooth the surface.

\section{Results}

Four types of opaque zones were identified. Briefly, Type A is a dark opaque zone, displaying minute, dense crystals, and is typically formed at a young life-history stage; Type $\mathrm{B}$ comprises an aggregation of grooves and discontinuous crystals that are formed during growth-stagnant periods; Type $\mathrm{C}$ has the appearance of an object that is smeared with ink; it is formed during seasons of active growth; Type D has deep grooves, appears luminous in transmitted light in etched otolith sections, and is formed during the spawning season. These four types of otolith opaque zone are described in detail in the following sections.

\section{Type A}

Otoliths of fishes generally have opaque cores. This core is surrounded by a translucent zone that is formed in the first year of life, with the exception of the Arabesque greenling Pleurogrammus azonus which has a long floating life of 1 year (Takashima et al. 2013). After the first year, an opaque zone is formed around the translucent zone, and these zones can be used to determine the age of the fish. In young fish, the whole otolith has an appearance of distinct zebra-like annuli, which are alternating opaque and translucent zones. Young rockfishes and flatfishes have otoliths in which the opaque zone can be easily analyzed by observing the surface of the whole otolith (Fig. 1).

In otolith sections, dark-brown zones correspond to areas that appear opaque using the surface observation method (Fig. 2). SEM observations reveal the presence of minute, dense crystals in these zones, which are typically formed at younger ages and are arrayed in these parts of the opaque zone and not in other parts of the translucent zone (Fig. 3).

This type of opaque zone seems to be traditional annuli. In general, the otolith nucleus and the zones formed during periods of rapid growth are composed of dense, opaque material that contains a high proportion of organic matter. Less dense, translucent, or hyaline material is deposited during periods of slower growth (Mugiya 1997). The formation of these alternating opaque and translucent zones and their use in age determination was reviewed 


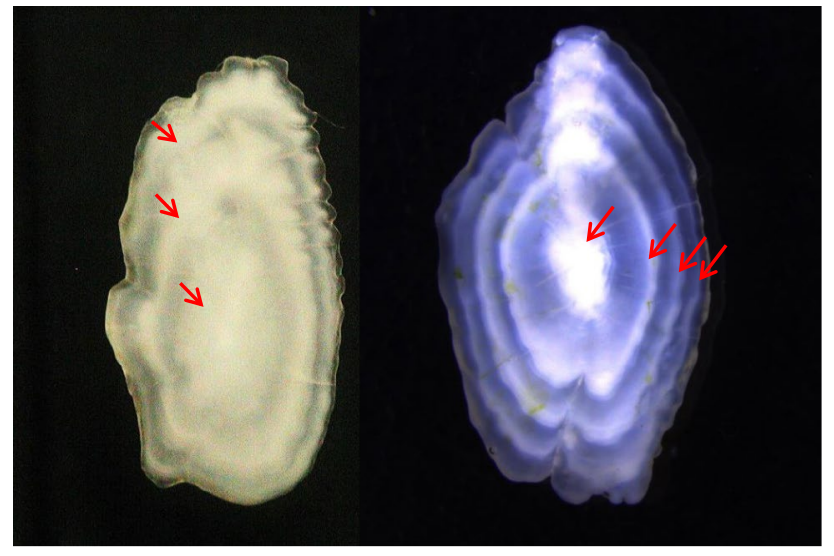

Fig. 1 Surface views of otolith of marbled flounder Pseudopleuronectes yokohamae (July 2015, Tokyo Bay, total length [TL] $271 \mathrm{~mm}$, male 2+) (left) and black rockfish Sebastes cheni (May 2012, Sendai Bay, TL 212 mm, male 4+) (right). Arrows indicate Type A opaque zones

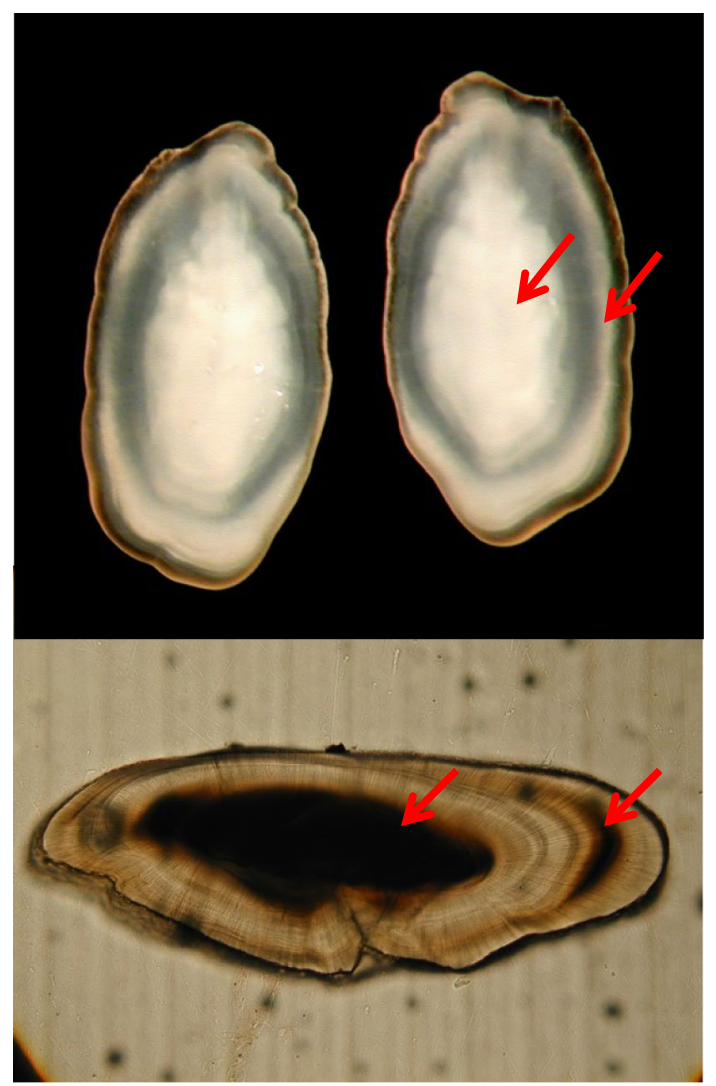

Fig. 2 Surface view of otolith (top) and transverse section of otolith (bottom) of sand lance Ammodytes japonicus (Dec. 2010, Ise Bay, TL $161 \mathrm{~mm}$ female 1). Arrows indicate Type A opaque zones

by Bagenal (1974) and Summerfelt (1987). Some of the mechanisms that have been attributed to the formations of
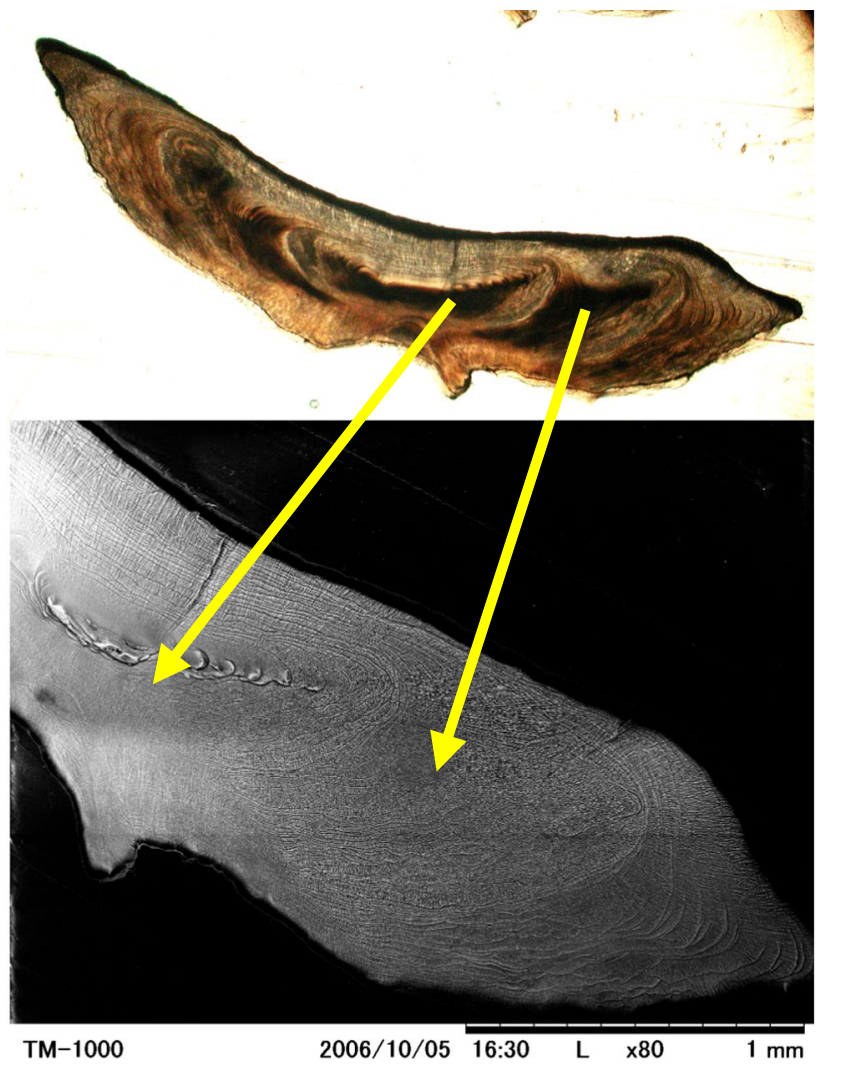

Fig. 3 Otolith section (top) and its scanning electronic microscopy (SEM) image (bottom) of Japanese flounder Paralichthys olivaceus (Feb. 2003, Tokyo Bay, TL 738 mm female 2+). Arrows indicate corresponding Type A opaque zones

zones in otoliths include the thickness and size of aragonite crystals (Morales-Nin 1987), organization of aragonite crystals (Jolivet et al. 2013), frequency of growth discontinuities and organic layers (Mugiya et al. 1985), ratio of calcium carbonate to protein matrix (Casselman 1974, 1982, 1987; Mugiya 1984), elemental ratios (Casselman 1982, 1983; Kalish 1989, 1991), and bioenergetic annual cycle (Gronkjaer 2016). A combination of these factors is believed to cause the differences in optical densities of the two zones (Wright et al. 2002).

The timing and seasonality of the formation of the opaque zones have been analyzed using monthly samples. Recently, individual data have been used for direct validation. The seasonal and annual formation of opaque zones has been investigated using the mark and recapture method (Szedlmayer and Beyer 2011; Cavole and Haimovici 2016; Peel et al. 2016) coupled with daily growth increments (Cavole and Haimovici 2016; Aldanondo et al. 2016). These studies determined that opaque zones were formed following the spawning period. 


\section{Type B}

As fish age, their otoliths become thicker, and surface observation becomes more difficult. Otolith sections, which reveal inner structures not visible on the surface, are generally used when the otoliths of older fish are analyzed. An example of an otolith section from black porgy Acanthopagrus schlegelii is shown in Fig. 4. The first translucent zone surrounding the dark opaque otolith core is not surrounded by dark opaque zones of Type A, but instead it is surrounded by a thin opaque structure that resembles a line. In Fig. 4 it can be seen that thin opaque zones are regularly arrayed around the otolith ridge. These thin opaque zones, classified as Type $\mathrm{B}$, are generally formed in older fish, in contrast to Type A opaque zones which are formed in younger fish (Cavole and Haimovici 2016). Zones of Type B (dark-colored opaque zone) can also be seen in an otolith section of the ridged-eye flounder Pleuronichthys lighti (Fig. 5, top). The structural characteristics are clearly visible in the SEM image (Fig. 5, middle and bottom). Aggregations of grooves and discontinuous structures are formed in the opaque zones.

A detailed examination of this structure reveals distinct changes in the direction of otolith growth (Fig. 6). The otolith initially grew in a dorsal-ventral direction in a transverse plane and became slightly warped with the aggregation of grooves. Subsequently, in and around the aggregation of grooves, the dorsal-ventral growth ceased and growth occurred proximally. Otolith growth in this proximal direction was short-lived and growth gradually returned to the former dorsal-ventral direction. Although the general direction of growth was dorsal-ventral in the transverse section, proximal growth was observed in later growth stages.

Investigations involving monthly sampling have shown that the formation of Type B opaque zones and the directional change in otolith growth occurs during the spawning season for many fish (Katayama et al. 2009, 2010, 2015; Katayama and Yamamoto 2012; Kawashima et al. 2017; Nagano et al. 2014; Tanaka et al. 2008; Yamada et al. 2011; Yamamoto and Katayama 2013; Yamashita et al. 2015). The aggregation of grooves may be caused by periods of stagnant somatic and otolith growth, while the directional change may be related to a shift from reproduction to growth. The alternative formation of Type A (recovery from spawning period) and B (spawning period) zones in Japanese flounder can be seen in Fig. 7.

As Type B zones are formed during the spawning period, the question arises whether this opaque zone marks the time of spawning. In validation experiments in which immature fish were reared, grooves were aggregated and directional change occurred during the spawning season (Fig. 8, ALC, Alizarin complexone, marked)
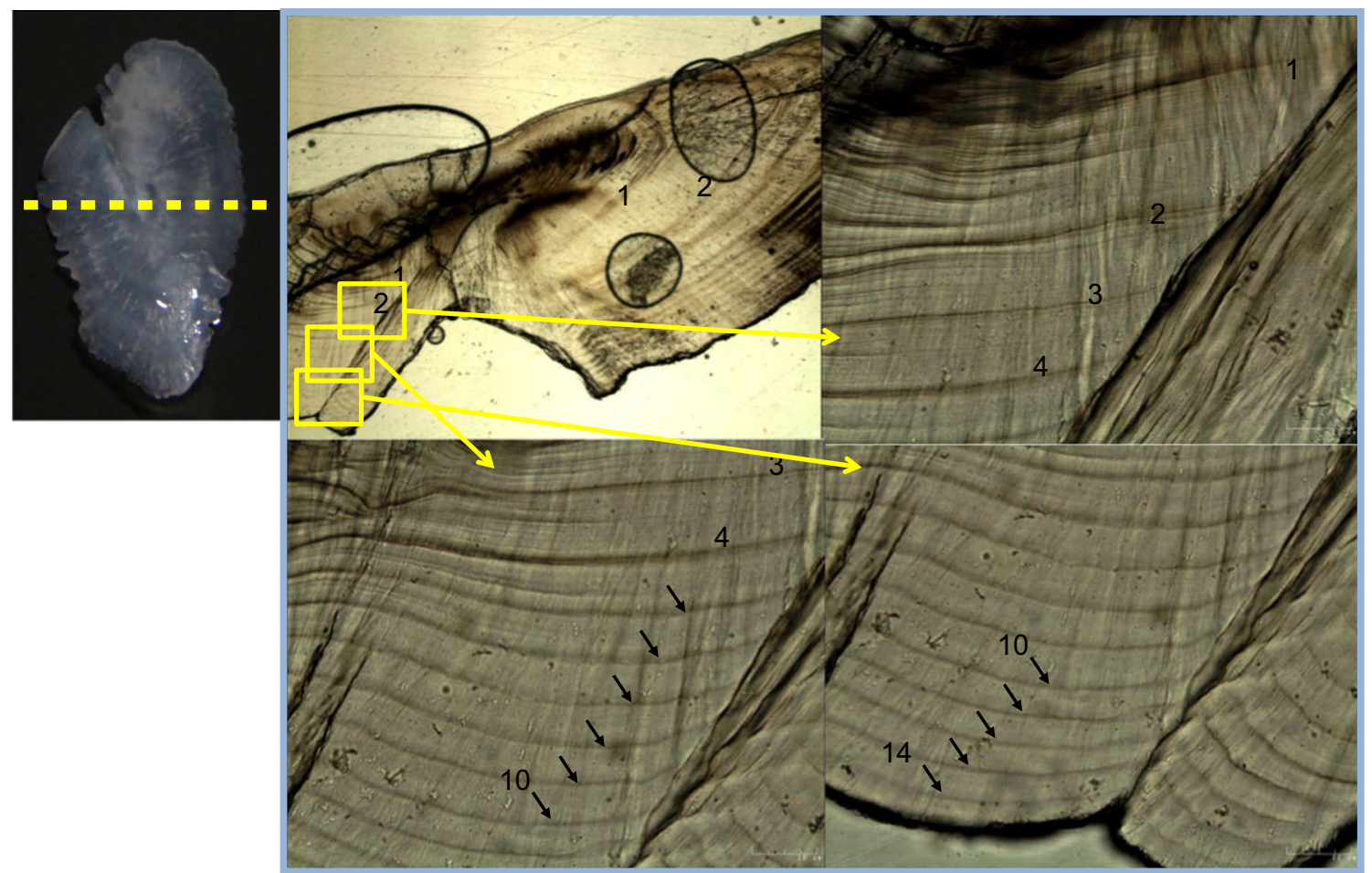

Fig. 4 Otolith surface view and sections of black porgy Acanthopagrus schlegeli (Apr. 2008, Tokyo Bay, fork length [FL] 471 mm female 14+). Arrows with numbers indicate Type B opaque zones 


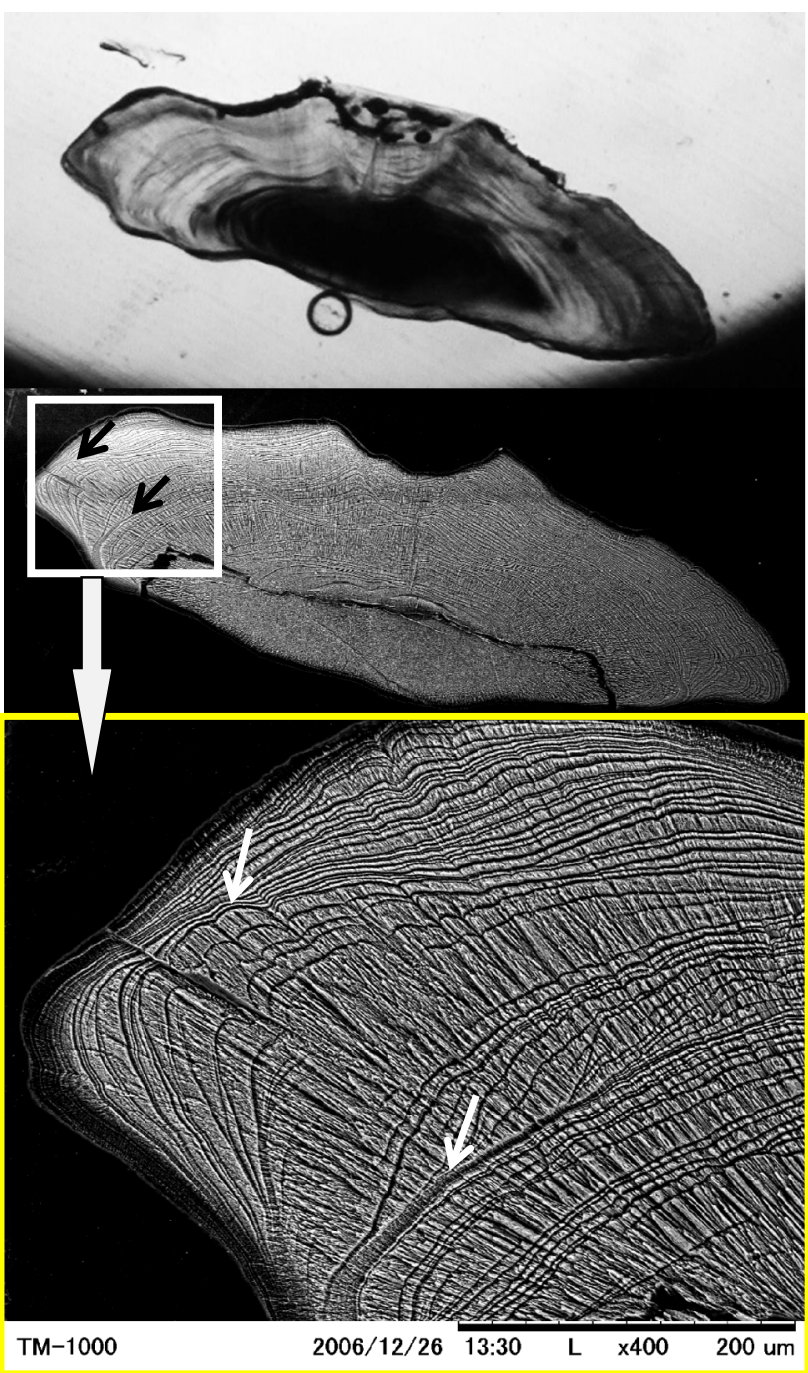

Fig. 5 Otolith section (top) and its SEM images (middle and bottom) of ridged-eye flounder Pleuronichthys lighti (Nov. 2005, Seto Inland Sea, TL $241 \mathrm{~mm}$ female 2+). Solid arrows indicate Type B opaque zones (Modified from Katayama et al. 2010)

in non-spawning flounder. This structure can therefore be related to a shift in the annual cycle of the fish, as mentioned above.

\section{Type C}

A type of opaque zone that differs from both Types A and B was found in the otolith of the Japanese jack mackerel Trachurus japonicus (Fig. 9). This zone, termed Type C, has a washy black zone appearance, as if smeared with ink; it is formed during seasons of active growth. The Type C opaque zone cannot be distinguished from the other types by SEM (Fig. 10), and it has not previously been identified as an opaque zone. However, Type $\mathrm{C}$ zones can be seen in the images presented in reports relating to black porgy

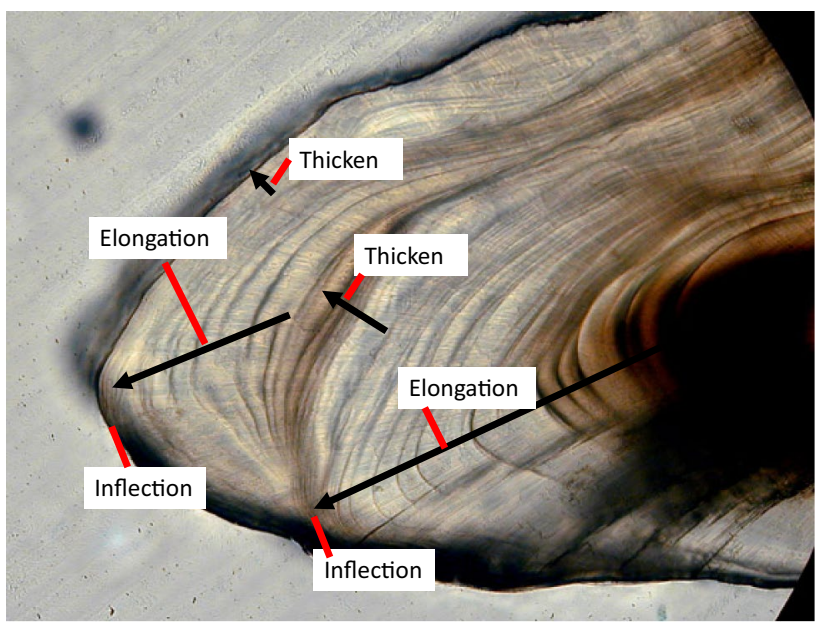

Fig. 6 Otolith section with explanations on the direction of otolith growth of the ridged-eye flounder Pleuronichthys lighti (Nov. 2005, Seto Inland Sea, TL $241 \mathrm{~mm}$ female 2+) (Modified from Katayama et al. 2010)

(Yamashita et al. 2015) and red tilefish Branchiostegus japonicus (Yamashita et al. 2011) (Fig. 11). Figure 9 shows the alternating formation of Type $\mathrm{B}$ and $\mathrm{C}$ zones, with Type $\mathrm{C}$ sandwiched between Type B zones. This insertion of Type $\mathrm{C}$ zones suggests that the seasonality of Type $\mathrm{C}$ formation is the opposite to that of Type B. As this is the first description of the Type $\mathrm{C}$ zone, the mechanisms and formation patterns have not been documented. The Type $\mathrm{C}$ opaque zone is believed to be formed during non-spawning growth periods.

\section{Type D}

Type D zones are observed as a deep groove that appears luminous in transmitted light in etched otolith sections. These zones are formed during the spawning season and can often be found within Type B zones. An example of a Type D zone in an otolith from dog tongue sole Cynoglossus robustus is shown in Fig. 12. This is the simplest structure, a deep groove that is coded as a Type D opaque zone. Although Type $\mathrm{D}$ zones have been considered to be an indication of the occurrence of a spawning period for many species (Onishi and Katayama 2010; Nishikawa et al. 2014; Yamamoto et al. 2009; Yamamoto and Katayama 2016), in the current study Type D zones were observed in young and immature individuals and, therefore, Type D zones do not necessarily indicate that spawning has taken place and cannot be considered as a "spawning check."

Williams and Bedford (1974), Watabe et al. (1982), and Wright et al. (2002) described Type D zones as follows: "Structural discontinuities also known as checks, are breaks within the regular arrangement of the primary increments. They generally appear after acid etching as deep grooves in the otolith surface and under the 
Fig. 7 Otolith section with explanations of the two types (A and B) of opaque zones of Japanese flounder Paralichthys olivaceus (May 2008, off Niigata Pref. TL $562 \mathrm{~mm}$ female $4+$ ). Solid (gray and black), double, and broken lines denote the positions of the opaque zones $(A, B)$, translucent zones $(t r)$, and otolith growth directions, respectively

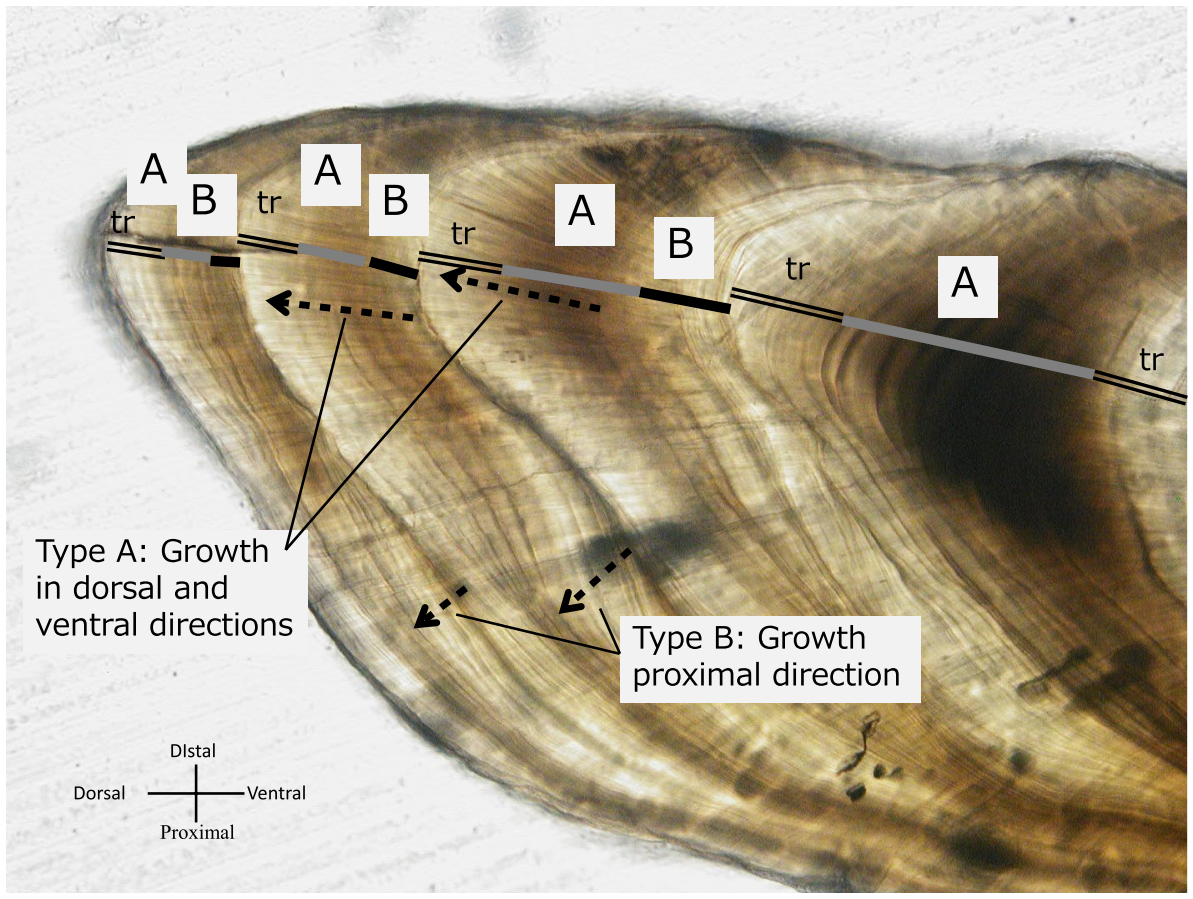

microscope they appear as wide dark zone." These authors did not examine the relation of this structure with the fish life cycle. Some studies have reported that characteristics of this "check" structure are related to stress, settlement, and stagnant activity (Wright et al. 2002). Wright et al. (2002) also stated that "When the duration of formation of a discontinuity is known, for example with a winter stress check, such structures can be useful for estimating annual age." While life-history events such as settlement and environmental stresses can result in the formation of otolith checks, in the current study the use of checks formed during the spawning season are considered to be important.

\section{Conclusion}

Alternative formations of opaque and translucent zones in fish otoliths are widely used for to determinate fish age. Various interpretations and explanations of the mechanisms causing annual periodicities in opaque zone formations have been put forward, including the presence of differing structures and different bioenergetics factors. To determine fish age and gain an understanding of the life cycles of fishes, researchers need precise knowledge of the opaque zones in the otoliths. The results of this review allow for the classification of four different types of opaque zone, as follows:
- Type A can be described as dark opaque zones that display minute, dense crystals and which are typically formed in the young stage.

- Type B comprises an aggregation of grooves and discontinuous crystals. These zones are formed during growthstagnant periods.

- Type $\mathrm{C}$ is a washy black zone which has the appearance of being smeared with ink and which is formed during seasons of active growth.

- Type D is observed as a deep groove, appearing luminous in transmitted light in etched otolith sections and is formed during the spawning season.

Types $\mathrm{A}$ and $\mathrm{C}$ are typically found in younger fish and are formed during the growth periods. These zones are complementary to Types B and D, which are formed during periods of stagnant growth and/or spawning. These latter two zones are more typical of older fish, in which Type A is absent. To ensure precise age determination, it is necessary to understand the structural and biological characteristics that produce these four distinct zone types.

\section{Recommendations}

\section{Methodology}

Surface observation methods and section observation methods can both be used in otolith analysis. Surface observations are associated with a greater ease of handling and 


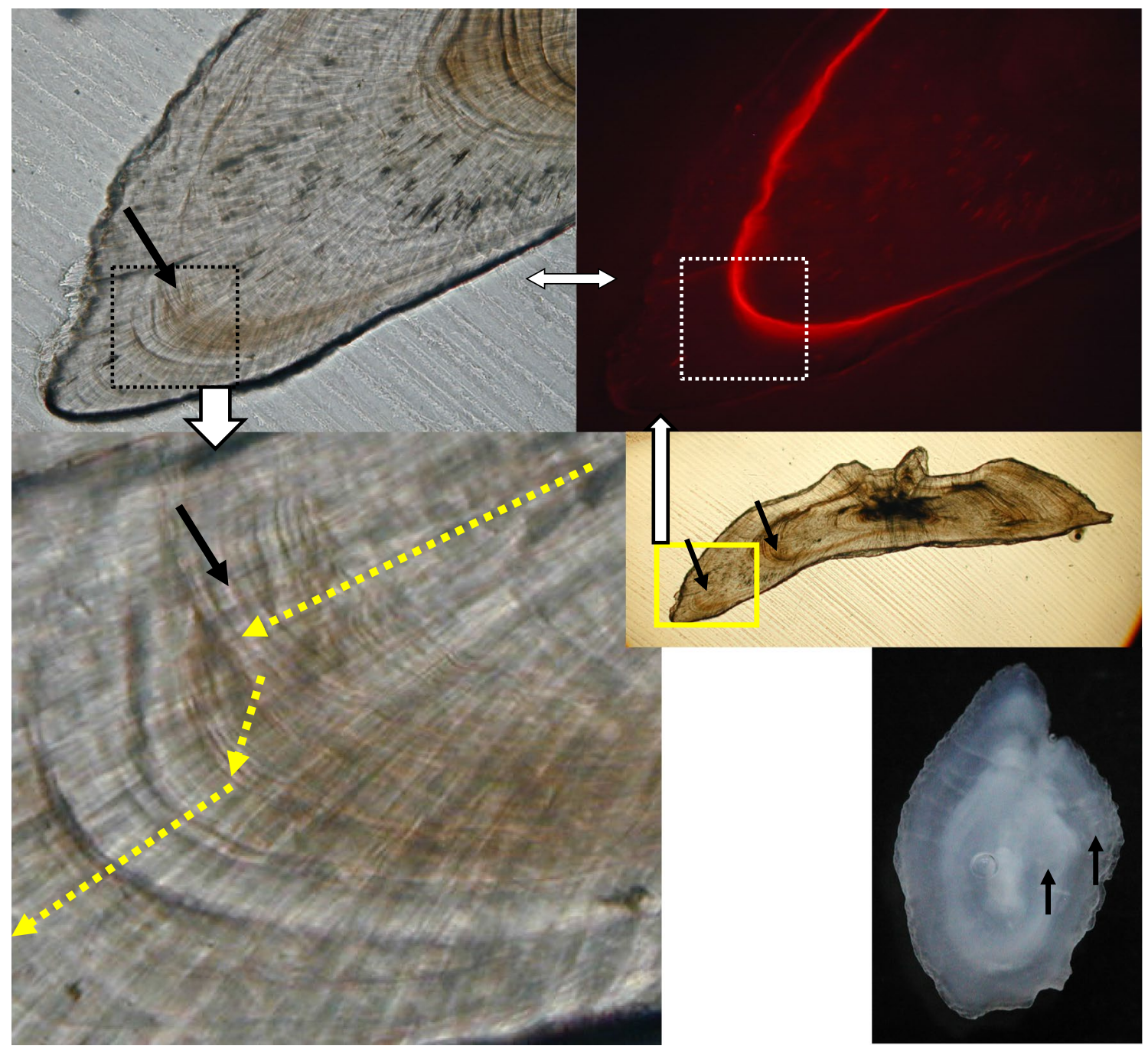

Fig. 8 Otolith sections of reared Japanese flounder Paralichthys

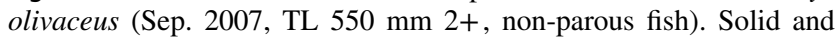
broken arrows denote positions of opaque zones and otolith growth directions, respectively. Top right photo shows ALC (Alizarin complexone) illumination under UV light (B-filter), taken during the

observation. Otoliths grow in the posterior-anterior and dorsal-ventral directions in young fish, but grow in a proximal direction, increasing in thickness, as the fish ages. It would appear that this growth is synchronized with a period of stagnant somatic growth that occurs once a fish has passed spawning age. Due to the increased thickness of the otolith, surface observation is unsuitable for age determination in older fish for which the section method is used; such studies have already been reported for some species (Hayashi et al. 1995; Sekigawa et al. 2002; Yamamoto et al. 2008). The section method allows for the observation of the array of annuli in the proximal part of otolith and surrounding the otolith ridge. Zones of Type $\mathrm{B}$ and $\mathrm{D}$ opaque zones are only visible in cross-section, and their presence can greatly spawning season. Bottom left photo indicates the change in the direction of otolith growth around the opaque zone (Type B) that occurs in the spawning season. Bottom right photo is a view of the otolith surfaceof the flounder; arrows indicate positions of the opaque zones

enhance the precision of age determinations. Types B and $\mathrm{D}$ opaque zones consist of an aggregation of grooves and/or discontinuous crystals which can be highlighted by etching; these two zones can be clearly observed under the microscope using transmitted light.

Broken-burnt (also known as burn-and-break or breaking and burning) methods have been used to determine the age of eels (Chisnall and Kalish 1993; Graynoth 1999), whiting (Polat and Gumus 1996; Fowler and Short 1998), horse mackerel (Alagador and Murta 2002; Abaunza et al. 2008), lemon sole (Smith 2014), aurora Rockfish (Thompson and Hannah 2010), and Lethrinus sp. (Ebisawa and Ozawa 2009). UV light observation of burnt otoliths has been used to determine the age of Conger eels (Katayama et al. 2002). 

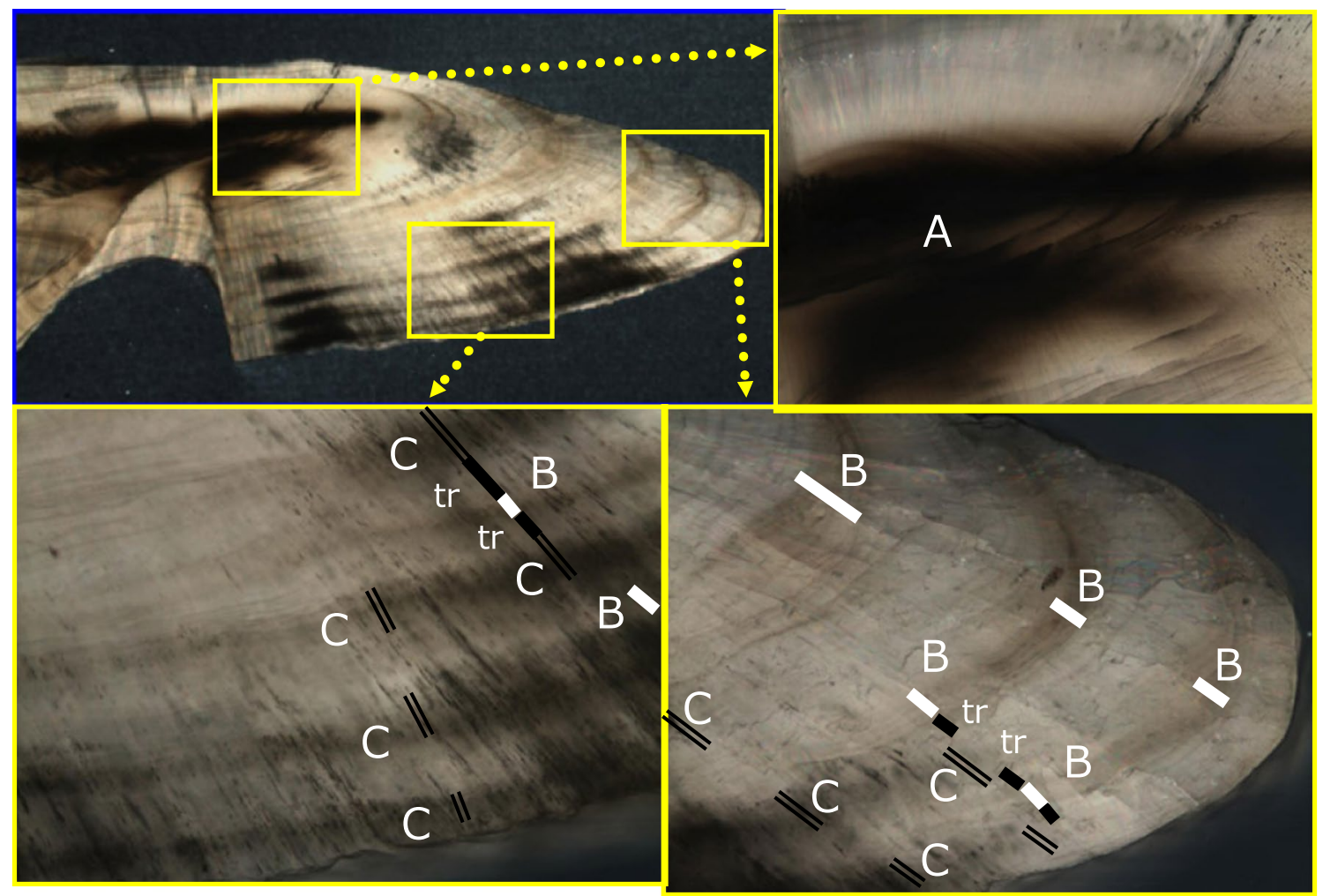

Fig. 9 Otolith sections of Japanese jack mackerel Trachurus japonicus (Apr. 2008, off Oita Pref., TL $354 \mathrm{~mm}$ female 4+). Three types of opaque zones $(A, B, C)$ are formed within an otolith. White, double and black lines denote positions of Type $\mathrm{B}$ and $\mathrm{C}$ opaque zones and translucent $(t r)$ zones, respectively
Fig. 10 Otolith sections and corresponding SEM images of the translucent part and Type $\mathrm{C}$ opaque zone of Japanese jack mackerel Trachurus japonicus (Dec. 2004, Sendai Bay, TL $383 \mathrm{~mm}$ female $12+$ )

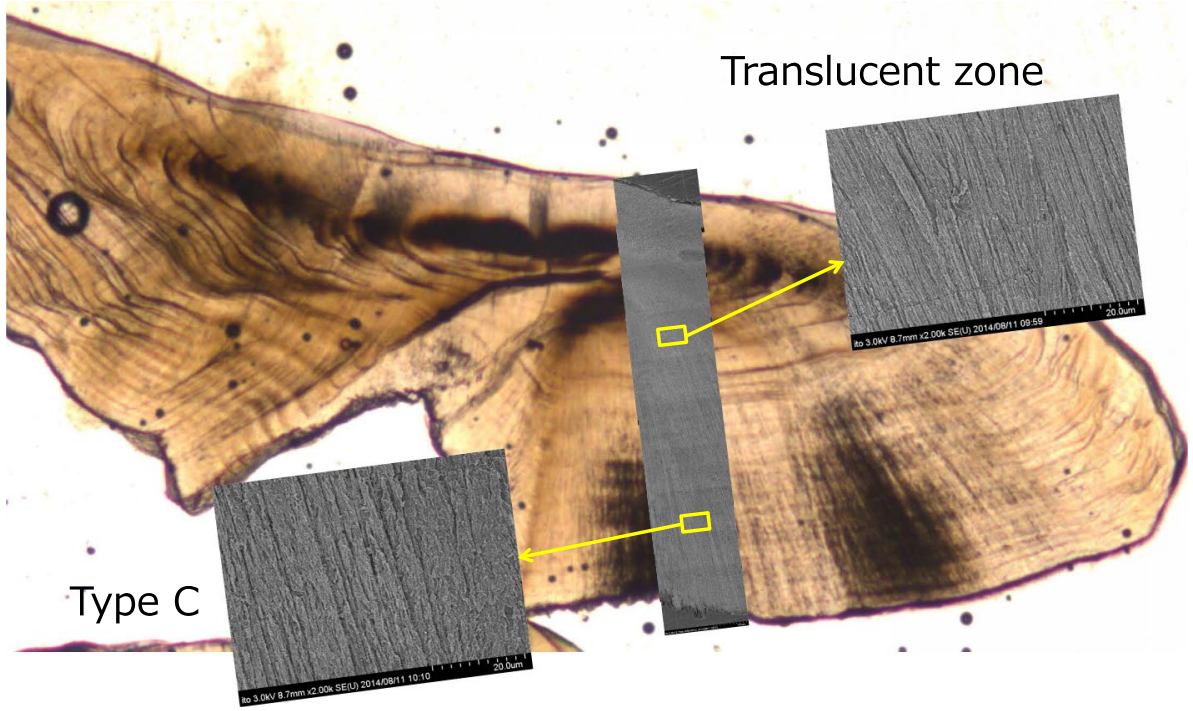

\section{False annuli}

It can often be difficult to determine the presence of a false annulus or to observe the first annulus in otoliths during age determination studies (Campana 2001). The identification of seasonal increments is complicated by the presence 


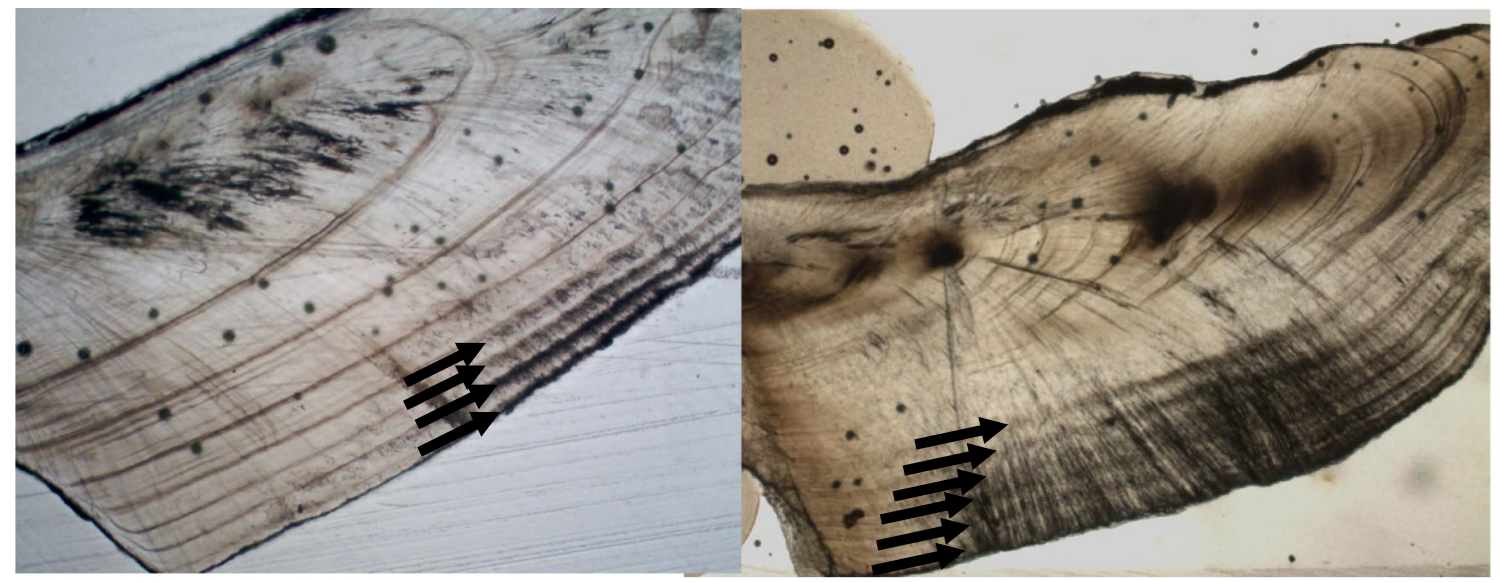

Fig. 11 Otolith sections of black porgy Acanthopagrus schlegeli (Oct. 2009, Tokyo Bay, FL 350 mm female 6+) (left) and red tilefish Branchiostegus japonicus (May. 2000, East China Sea, TL $412 \mathrm{~mm}$ male 7+) (right). Arrows indicate Type C opaque zones

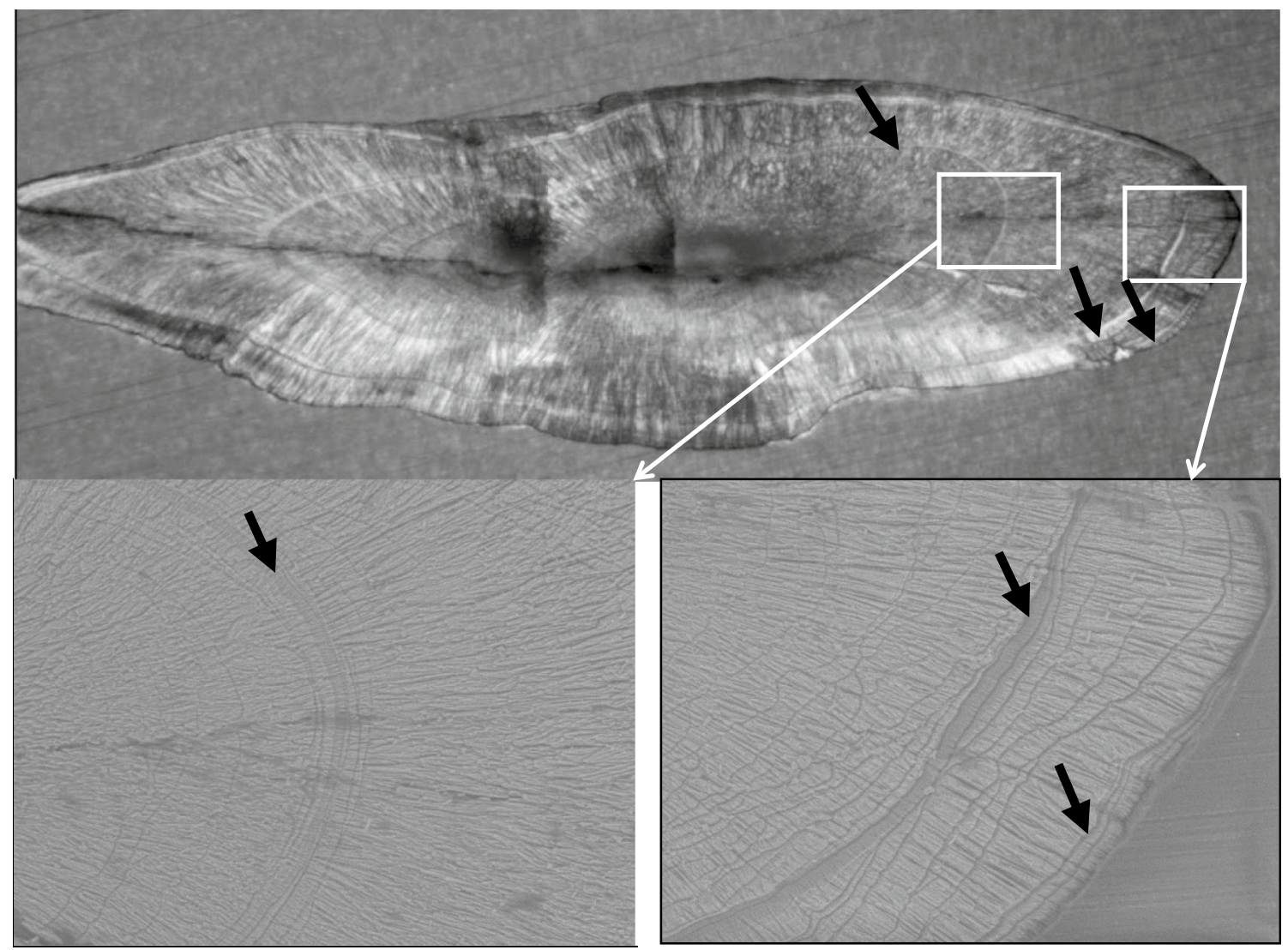

Fig. 12 Otolith sections (top) and SEM images (bottom) of Type D opaque zones of robust tongue sole Cynoglossus robustus (Aug. 2000, Seto Inland Sea, TL $253 \mathrm{~mm}$ female 3+) (Modified from Katayama and Yamamoto 2012)

of false annuli and discontinuous structures which correspond to non-seasonal events. False annuli are non-periodic secondary zones that appear as translucent zones within opaque zones. The mechanisms of their formation are not fully understood, although factors including temperature, oxidative stress, salinity, adverse weather, food intake, and developmental transitions have all been linked to their formation (Berghahn 2000; Cappo et al. 2000; Wright et al. 2002; Katayama and Isshiki 2006). The methodology for reading opaque and translucent zones is limited, and criteria 
to distinguish between seasonal zones and false annuli do not exist. As stated above, the directional change in otolith growth occurs during the spawning period, even if the fish is immature. This suggests that false annuli, which are abruptly formed in opaque zones, should accompany directional changes in otolith growth. Structural characteristics such these directional changes in otolith sections can be useful to distinguish between true annuli and false annual rings. It is therefore recommended that the sectioning method is used for a precise determination of age and discrimination of false annuli in fish of all ages.

Acknowledgements Funding The publication of this article was supported by the Japan Society for the Promotion of Science in a Grantin-Aid for Publication of Scientific Research Results (JSPS KAKENHI Grant number JP 262003).

Open Access This article is distributed under the terms of the Creative Commons Attribution 4.0 International License (http://creativeco mmons.org/licenses/by/4.0/), which permits unrestricted use, distribution, and reproduction in any medium, provided you give appropriate credit to the original author(s) and the source, provide a link to the Creative Commons license, and indicate if changes were made.

\section{References}

Abaunza PG, Santamaria LS, Garcia MT (2008) Life history parameters as basis for the initial recognition of stock management units in horse mackerel (Trachurus trachurus). Fish Res 89:167-180

Akamine T (2007) The foundation of analysis of fisheries stock. Koseisha-koseikaku, Tokyo (in Japanese)

Alagador D, Murta AG (2002) A comparison of staining techniques to improve precision of age estimation from fish otoliths. J Fish Biol 61:839-841

Aldanondo N, Cotano U, A'lvarez P, Uriarte A (2016) Validation of the first annual increment deposition in the otoliths of European anchovy in the Bay of Biscay based on otolith microstructure analysis. Mar Freshw Res 67:943-950

Bagenal TB (1974) Ageing of fish. In: Bagenal TB (ed) The proceedings of an international symposium on the ageing of fish. Unwin Brothers Ltd., London, pp 1-234

Beckman DW, Wilson CA (1995) Seasonal timing of opaque zone formation in fish otoliths. In: Secor DH, Dean JM, Campana SE (eds) Recent developments in fish otolith research. University of South Carolina Press, Columbia, pp 27-44

Berghahn R (2000) Response to extreme conditions in coastal areas: biological tags in flatfish otoliths. Mar Ecol Prog Ser 192:277-285

Campana SE (2001) Accuracy, precision and quality control in age determination, including a review of the use and abuse of age validation. J Fish Biol 59:197-242

Cappo M, Eden P, Newman SJ, Robertson S (2000) A new approach to validation on of periodicity and timing of opaque zone formation in the otoliths of eleven species of Lutianus from the central Great Barrier Reef. Fish Bull 98:474-488

Casselman JM (1974) Analysis of hard tissue of pike Esox lucius L. with special reference to age and growh. In: Bagenal TB (ed) The ageing of fish. Unwin Brothers Ltd., Old Woking, pp 13-27

Casselman JM (1982) Chemical analysis of the optically different zones in eel otoliths. In: Lufus K (ed) Proc 1980 North American Eel Conference. Ont Fish Tech Rep Ser 4:74-82
Casselman JM (1983) Age and growth assessment of fish from their calcified structure-techniques and tools. NOAA Tech Rep NMFS $8: 1-17$

Casselman JM (1987) Determination of age and growth. In: Gill HS, Weatherley AH (eds) The biology of fish growth, 1st edn. Academic, New York, pp 1-17

Cavole LM, Haimovici M (2016) The use of otolith microstructure in resolving issues of ageing and growth of young Micropogonias furnieri from southern Brazil. Mar Biol Res 11:933-943

Chisnall BL, Kalish JM (1993) Age validation and movement of freshwater eels (Anguilla dieffenbachii and A. australis) in a New Zealand pastoral stream. N Z J Mar Freshw Res 27:333-338

Ebisawa A, Ozawa T (2009) Life-history traits of eight Lethrinus species from two local populations in waters off the Ryukyu Islands. Fish Sci 75:553-566

Fablet R, Pecquerie L, de Pontual H, Høie H, Millner R, Mosegaard H, Ooijman S (2011) Shedding light on fish otolith biomineralization using a bioenergetic approach. PLoS One 6(11):e27055. https:// doi.org/10.1371/journal.pone.0027055

Fowler AJ, Short DA (1998) Validation of age determination from otoliths of the King George whiting Sillaginodes punctata (Perciformes). Mar Biol 130:577-587

Graynoth E (1999) Improved otolith preparation, ageing and backcalculation techniques for New Zealand freshwater eels. Fish Res 42:137-146

Gronkjaer P (2016) Otoliths as individual indicators: a reappraisal of the link between fish physiology and otolith characteristics. Mar Freshw Res 67:881-888

Hayashi A, Dotsu K, Ohta M (1995) Reliability of surface reading methods to count otolith opaque zones on aging in marbled rockfish Sebastiscus marmoratus compared with the cutaway reading method. Nippon Suisan Gakkaishi 61:1-5

Hoff GR, Fuiman LA (1993) Morphometry and composition of red drum otoliths: changes associated with temperature, somatic growth rate, and age. Comp Biochem Physiol A Physiol 106:209-219

Høie H, Folkvord A (2006) Estimating the timing of growth rings in Atlantic cod otoliths using stable oxygen isotopes. J Fish Biol 68:826-837

Hüssy K, Mosegaard H (2004) Atlantic cod (Gadus morhua) growth and otolith accretion characteristics modelled in a bioenergetics context. Can J Fish Aquat Sci 61:1021-1031

Iizuka K, Katayama S (2008) Otolith morphology of teleost fishes of Japan. Bull Fish Res Agen 25:1-222

Jolivet A, Bardeau JF, Fablet R, Paulet YM, Pontual H (2013) How do the organic and mineral fractions drive the opacity of fish otoliths? Insights using Raman microspectrometry. Can J Fish Aqua Sci 70:711-719

Jones CM (2002) Age and growth. In: Fuiman LA, Werner RG (eds) Fishery science, the unique contributions of early life stages. Blackwell, Oxford, pp 33-63

Kalish JM (1989) Otolith microchemistry: validation of the effects of physiology, age and environment on otolith composition. J Exp Mar Biol Ecol 132:151-178

Kalish JM (1991) Determinants of otolith chemistry: seasonal variation in the composition of blood plasma, endolymph and otoliths of beareded rock cod Pseudophycis barbatus. Mar Ecol Prog Ser 74:137-159

Katayama S, Isshiki T (2006) Variation in otolith macrostructure of Japanese flounder (Paralichthys olivaceus): discrimination of wild and released fish in developing a mass-marking system. J Sea Res 57:180-186

Katayama S, Yamamoto M (2012) Age, growth and stock status of robust tongue sole Cynoglossus robustus Günther, 1873 in Japan 
determined by a new otolith observation technique. Asian Fish Sci 25:206-217

Katayama S, Ishida T, Goto K, Iizuka K, Karita K (2002) A new aging technique of UV light observation of burnt otolith for Conger eel, Conger myriaster. Ichthyol Res 49:81-84

Katayama S, Akiyama S, Naganuma M, Saruta Y, Shibata R (2009) Age and growth of rabbitfish Siganus fuscescens in Tateyama Bay, Japan. Suisanzoshoku 57:417-422

Katayama S, Yamamoto M, Gorie S (2010) Age compositions of flatfish stocks as determined by a new otolithometric method, its application in the estimation of growth, spawning potential and fisheries management. J Sea Res 64:451-456

Katayama S, Akiyama S, Shimomura Y, Gurogi H (2015) Growth patterns and sex japonicas and C. erebennus in Tokyo Bay. Nippon Suisan Gakkaishi 81:688-693

Kawashima T, Ishii M, Katayama S (2017) Age determination of chub mackerel Scomber japonicus using otolith transverse section. J Fish Tech 9:45-51

Morales-Nin B (1987) The influence of environmental factors on microstructure of otoliths of three demersal fish species caught off Namibia. S Afr J Mar Sci 5:255-262

Morales-Nin B, Panfili J (2002) Age estimation. In: Panfili J, Pontual $\mathrm{H}$, Troadec H, Wright PJ (eds) Manual of fish sclerochronology. IRD Editions, Paris, pp 91-98

Mugiya Y (1984) Diurnal rhythm in otolith formation in the rainbow trout, Salmo gairdneri: seasonal reversal of the rhythm in relation to plasma calcium concentration. Comp Biochem Physiol 78A:289-293

Mugiya Y (1997) Formation of calcified tissues and their increments in fish. In: Akamine T, Mugiya Y (eds) Analysis of growth for aquatic animals. Koseisya Koseikaku, Tokyo, pp 9-16 (in Japanese)

Mugiya Y, Hirabayashi S, Ohsawa T (1985) Microradiography of otoliths and vertebral centra in the flatfish Limanda herzensteini, hypermineralization in the hyaline zone. Nippon Suisan Gakkaishi 51:219-225

Nagano M, Katayama S, Nakamura A, Kai S, Saito T (2014) Otolith reading method in age determination of red sea bream Pagrus major from Hyuga-nada. Bull Miyazaki Pref Fish Inst 15:1-8

Neilson JD, Geen GH (1985) Effects of feeding regimes and diel temperature cycles on otolith increment formation in juvenile Chinook salmon, Oncorhyncus tshawytscha. Fish Bull 83:91-101

Nishikawa T, Nakamura Y, Katayama S (2014) Age composition of Japanese Spanish Mackerel Scomberomorus niphonius (Cuvier 1832) Caught off Hyogo Prefecture, South-western Sea of Japan, as determined by the Otolith cross-section method. Asian Fish Sci 27:248-259

Onishi T, Katayama S (2010) Age and growth of Tanakius kitaharai (Jordan et Starks) off Niigata coast Japan, determined by transverse sections of otoliths. Bull Niigata Pref Fish Mar Res Inst 3:3-7

Peel RA, Taylor GC, Weyl OLF (2016) Validation of annulus formation in sagittal otoliths of three tropical cichlids Oreochromis andersonii (Castelnau, 1861), Oreochromis macrochir (Boulenger, 1912), and Coptodon rendalli (Boulenger, 1896). J Appl Ichthyol 32:859-865

Polat N, Gumus A (1996) Ageing of whiting (Merlangius merlangus euxinus, Nord, 1840) based on broken and burnt otolith. Fish Res 28:231-236
Sekigawa T, Takahashi T, Takatsu T (2002) Age and growth of fat greenling Hexagrammos otakii in Kikonai Bay, Hokkaido. Suisanzoshoku 50:395-400

Smith J (2014) Age validation of lemon sole (Microstomus kitt), using marginal increment analysis. Fish Res 157:41-46

Summerfelt RC, Hall GE (1987) Age and growth of fish. Iowa State University Press, Ames

Szedlmayer ST, Beyer SG (2011) Validation of annual periodicity in otoliths of red snapper, Lutjanus campechanus. Env Biol Fish 91:219-230

Takashima T, Hoshino N, Itaya K, Maeda K, Miyashita K (2013) Age validation using sectioned otoliths and age-size relationship for the Northern Hokkaido stock of the Arabesque greenling Pleurogrammus azonus. Nippon Suisan Gakkaishi 79:383-393

Tanaka T, Katayama S, Kato M, Meguro K (2008) Age and growth of Japanese flounder Paralichthys olivaceus around Choushi area, using transverse sections of otoliths. Bull Chiba Pref Fish Res Center 3:1-5

Thompson JE, Hannah RW (2010) Using cross-dating techniques to validate ages of aurora rockfish (Sebastes aurora): estimates of age, growth and female maturity. Env Biol Fish 88:377-388

Watabe N, Tanaka K, Yamada J, Dean JM (1982) Scanning electron microscope observations of the organic matrix in the otolith of the teleost fish Fundulus heteroclitus (Linnaeus) and Tilapia nilotica (Linnaeus). J Exp Mar Biol Ecol 58:127-134

Williams T, Bedford BC (1974) The use of otoliths for age determination. In: Bagenal TB (ed) The ageing of fish. Unwin Brothers Ltd., Old Woking, pp 114-123

Wright PJ, Panfili J, Morales-Nin B, Geffen AJ (2002) Types of calcified structures, Otoliths. In: Panfili J, Pontual H, Troadec H, Wright PJ (eds) Manual of fish sclerochronology. IRD Editions, Paris, pp 31-57

Yamada H, Katayama S, Takada A, Anraku Y, Sanada Y (2011) Age, growth and age composition of the landings of threeline grunt, Parapristipoma trilineatum, in the western Bungo Channel, Japan. Bull Jpn Soc Fish Oceanogr 75:161-169

Yamamoto M, Katayama S (2013) Age, growth and spawning period of bamboo sole Heteromycteris japonica in the Seto Inland Sea, Japan. Suisanzoshoku 61:359-365

Yamamoto M, Katayama S (2016) Growth and spawning period of ridged-eye flounder Pleuronichthys lighti Wu 1929 in the central Seto Inland Sea, Japan. Asian Fish Sci 29:112-123

Yamamoto M, Katayama S, Makino H, Takemori H (2008) Age, growth, and age composition of tonguefish, Cynoglossus abbreviatus, in the central Seto Inland Sea, Japan. Bull Jpn Soc Fish Oceanogr 72:174-181

Yamamoto M, Katayama S, Makino H, Takemori H (2009) Age and growth of tonguefish Cynoglossus joyneri in the central Seto Inland Sea, Japan. Aquacul Sci 57:341-342

Yamashita H, Sakai T, Katayama S, Tokai T (2011) Re-examination of growth and maturation of red tilefish Branchiostegus japonicus in the East China Sea. Nippon Suisan Gakkaishi 77:188-198

Yamashita H, Katayama S, Komiya T (2015) Age and growth of black sea bream Acanthopagrus schlegelii in Tokyo Bay. Asian Fish Sci 28:47-59 